\title{
Muscle Mass and Composition in Malnourished Infants and Children and Changes Seen after Recovery
}

\author{
P. J. REEDS, A. A. JACKSON, D. PICOU, AND N. POULTER ${ }^{(38)}$ \\ Tropical Metabolism Research Unit, University of the West Indies, Mona, Kingston, Jamaica, West Indies
}

\begin{abstract}
Summary
A method for measuring muscle mass in children with $\left[{ }^{15} \mathrm{~N}\right]$ creatine has been used to study changes in muscle after recovery from protein-energy malnutrition. Creatine pool size, muscle mass, total muscle cell number, muscle cell size, and total body water have been measured in seven malnourished and eight recovered children. After recovery there was a significant reduction in the muscle concentration (micrograms $\mathrm{mg}^{-1}$ wet wt muscle) of creatine (4.21 to 3.12$)$, and a trend towards reduction in noncollagen protein (155 to 136) and DNA (2.13 to 1.34). The fractional turnover rate of creatine did not change but the creatine pool size increased significantly $(4.2$ to $5.6 \mathrm{~g})$. Average muscle mass almost doubled $(1.00$ to $1.91 \mathrm{~kg})$ and made up a greater percentage of body weight (16 to $22 \%$ ). When muscle mass was expressed as a percentage of the expected muscle mass for a normal child of the same height the increase with recovery was from $49 \%$ to $92 \%$. Total muscle noncollagen protein (NCP) increased after recovery (153 to 265 g) and accounted for a greater percentage of total body solids (6.6 to 8.5\%). The average total muscle DNA was $2.049 \mathrm{~g}$ in the malnourished and $2.380 \mathrm{~g}$ in the recovered children and the ratio of NCP:DNA increased from 92 to 110 on recovery. Total body water as a percentage of body weight was not significantly different after recovery. Values for muscle mass in recovered children were similar to those reported for normal children of the same weight, height, and age.
\end{abstract}

\section{Speculation}

In children who have recovered from malnutrition by reaching their expected weight for height, muscle mass repletion is achieved by a combination of cellular hypertrophy and hyperplasia.

Muscle tissue provides the largest store of potentially available protein in the body (29) and is considerably reduced in the children with severe protein-energy malnutrition (PEM). From cadaver studies of children dying of severe PEM, the deficit in muscle was estimated to be about $70 \%$ based on either wet weight $(18)$ or total muscle protein $(15,29)$. Muscle biopsy data showed a $45 \%$ reduction in total protein in malnourished as compared to recovered children (31). Both the size and the total number of muscle fibers were considerably smaller in the sartorius muscle, obtained at postmortem, of malnourished as compared to well nourished children (23). During recovery from PEM there is an accelerated rate of weight gain (2), and the daily excretion of creatinine has been used as an indirect index of muscle mass in malnourished and recovered children $(1,7$, $13,27)$. However, the validity of creatinine excretion as a reliable measure of muscle mass in the malnourished child remains to be established. This is important since changes in muscle cell size and total cell number during recovery from PEM have been based on this method of estimating muscle mass (7)

Recently we reported a more direct method of measuring muscle mass in children (25). This method has been used in the present study to determine quantitative changes in muscle mass, total cell number, and functional cell size in malnourished and recovered children. These results and those of total body water measurements are reported in this paper.

\section{MATERIALS AND METHODS}

The method for measuring total muscle mass in vivo with $\left[{ }^{15} \mathrm{~N}\right]$ creatine has been described in detail (25). A tracer dose of $\left[{ }^{15} \mathrm{~N}\right]$ creatine was injected intravenously to label total body creatine nearly all of which is in muscle $(22,32)$. The loss of excess ${ }^{15} \mathrm{~N}(34)$ in urinary creatinine followed a monoexponential process from which the turnover rate of the muscle creatine pool was determined. From a knowledge of this and of daily urinary creatinine output, the size of the muscle creatine pool was calculated. Muscle mass was then estimated from the creatine pool size after measurement of the concentration of creatine in a muscle sample obtained by biopsy.

Urinary creatinine was measured by the Jaffe method. Isolation and purification of urinary creatinine and its analysis for ${ }^{15} \mathrm{~N}$ abundance by mass spectrometry have been previously described (25). Creatine was measured enzymically (3). Muscle DNA was measured by the method of Kissane and Robins (20) with minor modifications. Total protein and noncollagen protein were assayed by a modification (31) of the Lowry method (21). The creatine, DNA, and protein were measured on muscle samples, obtained at biopsy, which weighed between 5 and $16 \mathrm{mg}$ wet wt. All measurements were carried out in duplicate against a known standard. In preliminary studies on rat tissue values comparable to those in the literature were obtained for all the measurements. No studies have been performed on normal human biopsies.

Muscle "cell number" was calculated by dividing the total muscle DNA by $6.2 \mathrm{pg}(11)$, and muscle "cell size" by dividing total muscle noncollagen protein (in grams) by total muscle DNA (8).

Total body water was measured by the technique of isotope dilution. A tracer dose of tritiated water was administered intravenously and its dilution was determined from the specific activity of plasma water from a blood sample obtained $3 \mathrm{hr}$ after the injection of tracer. The dose was $0.2 \%$ of the recommended safe whole body dose which yielded counts 50-100\% above background. The biologic half-life of the tracer was $30 \mathrm{hr}$.

\section{PATIENTS}

Seven malnourished children (malnourished group) were studied in a metabolic unit. Their ages, diagnoses, and anthro- 
Table 1. Clinical state of malnourished and recovered subjects

\begin{tabular}{|c|c|c|c|c|c|c|c|c|}
\hline Subject & $\begin{array}{l}\text { Age, } \\
\text { mo }\end{array}$ & $\mathrm{Wt},{ }^{1} \mathrm{~kg}$ & $\begin{array}{c}\mathrm{Wt}^{2} \\
\text { for age, } \\
\%\end{array}$ & $\mathrm{Ht}, \mathrm{cm}$ & $\begin{array}{c}\mathrm{Ht} \\
\text { for age, } \\
\%\end{array}$ & $\begin{array}{c}\text { Wt for ht } \\
\%\end{array}$ & $\begin{array}{l}\text { Day of } \\
\text { study }\end{array}$ & Diagnosis $^{3}$ \\
\hline \multicolumn{9}{|c|}{ Malnourished group } \\
\hline $\mathrm{KG}$ & 8 & 3.970 & 46 & 62 & 89 & 64 & 1 & Marasmus \\
\hline DA & 9 & 5.280 & 58 & 69 & 97 & 63 & 3 & Marasmus \\
\hline DJ & 11 & 4.438 & 46 & 61.5 & 83 & 73 & 4 & Marasmus \\
\hline GF & 12 & 6.166 & 61 & 71 & 94 & 69 & 1 & Undernourished \\
\hline MT & 15 & 7.722 & 72 & 78 & 99 & 73 & 1 & Kwashiorkor \\
\hline ED & 17 & 5.950 & 53 & 73 & 90 & 63 & 1 & Marasmus-kwashiorkor \\
\hline CR & 26 & 10.224 & 79 & 84.75 & 95 & 8.5 & 3 & Kwashiorkor \\
\hline Mean & 14.0 & 6.250 & 59 & 71.32 & 92 & 70 & & \\
\hline $\mathrm{SD}$ & 5.92 & 2.14 & 12.6 & 8.33 & 5.5 & 7.9 & & \\
\hline \multicolumn{9}{|l|}{ Recovered group } \\
\hline RW & 4 & 4.280 & 68 & 56.5 & 91 & 90 & & \\
\hline $\mathrm{DA}$ & 12 & 9.360 & 94 & 72.5 & 97 & 100 & & \\
\hline $\mathrm{HC}$ & 13 & 5.219 & 51 & 58 & 76 & 101 & & \\
\hline DJ & 13 & 7.934 & 77 & 67 & 88 & 102 & & \\
\hline $\mathrm{BJ}$ & 15 & 9.524 & 89 & 75 & 96 & 95 & & \\
\hline $\mathrm{OJ}$ & 16 & 8.605 & 78 & 73 & 92 & 90 & & \\
\hline MT & 18 & 10.845 & 95 & 80.5 & 98 & 97 & & \\
\hline CR & 27 & 13.180 & 101 & 86 & 96 & 107 & & \\
\hline Mean & 14.75 & 8.618 & 82 & 71.06 & 92 & 98 & & \\
\hline $\mathrm{SD}$ & 6.5 & 2.878 & 16.6 & 10.23 & 7.2 & 6.0 & & \\
\hline
\end{tabular}

' Lowest weight after admission.

${ }^{2}$ Boston standard 50th centile.

${ }^{3}$ Based on the Wellcome classification (33).

Table 2. Total body water and body solids in malnourished and recovered subjects

\begin{tabular}{|c|c|c|c|c|}
\hline \multirow[b]{2}{*}{ Subject } & \multicolumn{2}{|c|}{ Total body water } & \multicolumn{2}{|c|}{ Total body solids } \\
\hline & Liter & $\% \mathrm{Wt}$ & $\mathrm{Kg}$ & $\% \mathrm{Wt}$ \\
\hline \multicolumn{5}{|c|}{ Malnourished } \\
\hline KG & 2.695 & 59 & 1.849 & 41 \\
\hline DA & 3.548 & 66 & 1.837 & 34 \\
\hline $\mathrm{DJ}$ & 2.849 & 64 & 1.570 & 36 \\
\hline GF & 4.057 & 66 & 2.090 & 34 \\
\hline MT & 6.398 & 68 & 3.002 & 32 \\
\hline ED & 4.307 & 66 & 2.268 & 34 \\
\hline $\mathrm{CR}$ & 6.131 & 58 & 4.367 & 42 \\
\hline Mean & 4.284 & 64 & 2.426 & 36 \\
\hline SD & 1.475 & 3.8 & .970 & 3.8 \\
\hline \multicolumn{5}{|l|}{ Recovered } \\
\hline RW & 2.829 & 66 & 1.451 & 34 \\
\hline $\mathrm{DA}$ & 6.186 & 66 & 3.174 & 34 \\
\hline $\mathrm{HC}$ & N.A. ${ }^{1}$ & N.A. & N.A. & N.A. \\
\hline DJ & 5.340 & 67 & 2.594 & 33 \\
\hline $\mathrm{BJ}$ & 5.942 & 62 & 3.582 & 38 \\
\hline OJ & 4.827 & 56 & 3.778 & 44 \\
\hline $\mathrm{MT}$ & 7.042 & 65 & 3.803 & 35 \\
\hline CR & 8.152 & 62 & 5.028 & 38 \\
\hline Mean & 5.760 & 63 & 3.344 & 37 \\
\hline SD & 1.693 & 3.8 & 1.033 & 3.8 \\
\hline
\end{tabular}

${ }^{1}$ Not available.

pometric data are shown in Table 1. All seven studies were done within 4 days of admission when the children were receiving a milk-based formula on which their body weight was maintained. After the initial study, children were given a high energy, milkbased diet on which they gained weight rapidly (19). Eight children were studied after they had recovered from PEM. They included four children who were also studied when they were malnourished. The ages and anthropometric data of children in the recovered group are shown in Table 1. Full and informed parental consent was obtained for each study performed.
Table 3. Creatinine output, creatine turnover, and pool size and creatinine height index in malnourished and recovered subjects

\begin{tabular}{lcccc} 
& & \multicolumn{2}{c}{ Creatine } \\
\cline { 3 - 4 } & $\begin{array}{c}\text { Urinary } \\
\text { creatinine, }\end{array}$ & $\begin{array}{c}\text { Fractional } \\
\text { turnover, } \\
\text { Subject }\end{array}$ & $\begin{array}{c}\text { Pool size, } \\
\mathrm{mg} \mathrm{kg}^{-1} \text { day }^{-1}\end{array}$ & $\begin{array}{c}\text { Creatinine } \\
\text { \%t index }\end{array}$ \\
\hline Malnourished & & & & \\
KG & 13.07 & 2.38 & 2.890 & 0.81 \\
DA & 11.85 & 2.14 & 3.449 & 0.68 \\
DJ & 11.00 & 1.59 & 3.554 & 0.70 \\
GF & 12.42 & 2.46 & 3.601 & 0.76 \\
MT & 8.74 & 2.42 & 3.933 & 0.63 \\
ED & 10.75 & 1.93 & 4.252 & 0.65 \\
CR & 10.06 & 1.61 & 7.591 & 0.64 \\
Mean & 11.13 & 2.08 & 4.181 & 0.69 \\
SD & 1.47 & 0.373 & 1.561 & 0.06 \\
Recovered & & & & \\
RW & 11.86 & 1.53 & 3.853 & 0.94 \\
DA & 11.22 & 2.63 & 4.635 & 0.98 \\
HC & 11.75 & 2.33 & 3.051 & 1.04 \\
DJ & 12.02 & 1.87 & 5.906 & 1.10 \\
BJ & 10.77 & 2.43 & 4.902 & 0.87 \\
OJ & 12.47 & 2.42 & 5.146 & 0.98 \\
MT & 11.99 & 2.38 & 6.338 & 0.92 \\
CR & 11.63 & 1.61 & 11.042 & 0.89 \\
Mean & 11.71 & 2.15 & 5.609 & 0.97 \\
SD & 0.522 & 0.418 & 2.432 & 0.08 \\
\hline
\end{tabular}

\section{RESULTS}

Where applicable statistical analyses were carried out. Differences between the malnourished and recovered groups were tested for statistical significance by Student's $t$-test. Where groups' variance were significantly different, the Behring Fisher test was used (26).

The mean age and height of the malnourished group (14.0 months and $71.3 \mathrm{~cm})$ were similar to the recovered group $(14.8$ months and $71.1 \mathrm{~cm}$ ). The mean percentage weight for height 
was significantly greater after recovery $(P<0.001)$ than in the malnourished state (Table 1).

Table 2 shows that in the malnourished children the average total body water ( 4.3 liters) and total body solids $(2.4 \mathrm{~kg}$ ) were reduced as compared to the recovered children (5.8 liters and $3.3 \mathrm{~kg})$. In the paired studies this difference was significant $(P$ $<0.05)$. However, when expressed as a percentage of total body weight, mean total body water (TBW\%) and total body solids (65\% and $35 \%$, respectively) in the malnourished group did not differ from the values found after recovery $(63 \%$ and $37 \%)$. The average urinary creatinine was not significantly greater in the recovered $\left(11.7 \mathrm{mg} \mathrm{kg}^{-1} \mathrm{day}^{-1}\right)$ than the malnourished (11.1 mg kg-1 $\mathrm{day}^{-1}$ ) children (Table 3). There was a significant increase $(P<0.005)$ in the mean creatinine height

Table 4. Muscle biopsy data in malnourished and recovered subjects

\begin{tabular}{|c|c|c|c|c|c|}
\hline Subject & $\begin{array}{c}\text { Creatine, } \\
\mu \mathrm{g} \mathrm{mg}^{-1} \\
\text { wet wt } \\
\text { muscle }\end{array}$ & $\begin{array}{c}\mathrm{NCP} \\
\mu \mathrm{g} \mathrm{mg}^{-1} \\
\text { wet wt } \\
\text { muscle }\end{array}$ & $\begin{array}{l}\text { DNA, } \\
\mu \mathrm{g} \mathrm{mg}^{-1} \\
\text { wet wt } \\
\text { muscle }\end{array}$ & $\begin{array}{l}\text { Creatine } \\
\text { /NCP, \% }\end{array}$ & $\begin{array}{c}\text { Creatine } \\
\text { /DNA, } \\
\mathrm{g} / \mathrm{g}\end{array}$ \\
\hline \multicolumn{6}{|c|}{ Malnourished } \\
\hline $\mathrm{KG}$ & 4.436 & 192.2 & 1.166 & 2.31 & 3.80 \\
\hline DA & 4.440 & 161.4 & 2.078 & 2.75 & 2.14 \\
\hline DJ & 3.941 & 133.6 & 2.095 & 2.95 & 1.88 \\
\hline GF & 3.966 & 129.7 & 1.790 & 3.06 & 2.22 \\
\hline MT & 4.88 & 156.4 & 4.100 & 3.12 & 1.19 \\
\hline ED & 3.18 & 171.6 & 2.835 & 1.85 & 1.12 \\
\hline CR & 4.607 & 138.7 & 0.824 & 3.32 & 5.59 \\
\hline Mean & 4.207 & 154.8 & 2.127 & 2.77 & 2.66 \\
\hline $\mathrm{SD}$ & 0.563 & 22.6 & 1.090 & 0.52 & 1.15 \\
\hline \multicolumn{6}{|l|}{ Recovered } \\
\hline RW & 2.970 & 127.6 & 1.189 & 2.33 & 2.50 \\
\hline $\mathrm{DA}$ & 2.922 & 136.8 & 1.730 & 2.14 & 1.69 \\
\hline $\mathrm{HC}$ & 3.001 & 122.5 & 1.056 & 2.45 & 2.84 \\
\hline $\mathrm{DJ}$ & 3.587 & 164.6 & 1.912 & 2.18 & 1.88 \\
\hline $\mathrm{BJ}$ & 3.463 & 143.5 & 0.900 & 2.41 & 3.85 \\
\hline $\mathrm{OJ}$ & 3.448 & 152.3 & 1.787 & 2.26 & 1.93 \\
\hline MT & 3.316 & 95.0 & 1.269 & 3.50 & 2.61 \\
\hline CR & 2.247 & 148.6 & 0.850 & 1.51 & 2.64 \\
\hline Mean & 3.119 & 136.4 & 1.337 & 2.35 & 2.49 \\
\hline $\mathrm{SD}$ & 0.434 & 21.5 & 0.418 & 0.55 & 0.69 \\
\hline
\end{tabular}

index after recovery $(0.68$ to 0.97$)$. The fractional turnover rate of creatine in the malnourished (mean $2.05 \%$ day $^{-1}$ ) and the recovered children $\left(2.15 \%\right.$ day $\left.^{-1}\right)$ did not differ significantly, although the creatine pool size increased significantly in the paired studies. The muscle biopsy data are shown in Table 4. There was a small but significant reduction in the average muscle concentration of creatine (4.21 to $3.12 \mu \mathrm{g} \mathrm{mg}^{-1}$ wet wt muscle, $P<0.05)$ on recovery. The increase in the concentration of noncollagen protein and DNA after recovery did not reach significance. The average muscle mass after recovery (Table 5) was almost twice that found in the malnourished group (1.91 versus $1.00 \mathrm{~kg}$ wet $\mathrm{wt}$, respectively). In the paired studies the average increase in muscle mass was $130 \%$ and this accounted for a greater percentage of body weight (mean 56\% range 1 to $131 \%$ ). The muscle mass expressed as a percentage of the normal for a child of the same height increased on average from $49 \%$ in the malnourished to $92 \%$ on recovery. The average increase in muscle noncollagen protein with recovery was from $153 \mathrm{~g}$ to $265 \mathrm{~g}$, an increase of $116 \%$ in the paired studies. The noncollagen protein accounted for a greater percentage of total body solids in the recovered $(8.5 \%)$ as compared to the malnourished group $(6.6 \%)$, a paired increase of $56 \%$. The average muscle DNA in the malnourished $(2.05 \mathrm{~g})$ was lower than the recovered $(2.38 \mathrm{~g})$ and there was a paired increase of $55 \%$ with recovery. Similarly there was an increase in the ratio of noncollagen protein to DNA from 92 to 110 , a $34 \%$ increase for the paired values.

\section{DISCUSSION}

The value obtained for muscle mass is that at a single point in time when the muscle biopsy is taken. However, a single study extended over an average period of 4 weeks, because weekly samples of urine were needed in order to determine the kinetics of creatine catabolism. During this time a marked improvement in the nutritional status of the malnourished children had occurred. Yet the creatine turnover in any one individual remained remarkably constant. This is shown in the malnourished group where there was a high average correlation coefficient $(r=-0.937)$ of the slope of the line expressing the monoexponential loss of isotope. Furthermore, there was no significant difference in the average creatine turnover rates between the malnourished and recovered groups. We conclude from these findings that creatine turnover is unaffected by

Table 5. Muscle mass (MM) data in malnourished and recovered subjects

\begin{tabular}{|c|c|c|c|c|c|c|c|c|}
\hline Subject & $\mathrm{MM}, \mathrm{kg}$ & $\mathrm{MM} / \mathrm{wt}, \%$ & $\begin{array}{l}\text { MM expected for } \\
\text { ht, } \%\end{array}$ & $\mathrm{NCP}, \mathrm{g}$ & $\begin{array}{c}\mathrm{NCP} / \text { total } \\
\text { body solids \% }\end{array}$ & DNA, g & $\begin{array}{c}\text { Muscle nuclei, } \\
\times 10^{12}\end{array}$ & $\mathrm{NCP}: D N A, \mathrm{~g} / \mathrm{g}$ \\
\hline \multicolumn{9}{|l|}{ Malnourished } \\
\hline KG & 0.652 & 14 & 46 & 125 & 6.8 & 0.760 & 0.123 & 165 \\
\hline DA & 0.777 & 14 & 41 & 125 & 6.8 & 1.615 & 0.260 & 78 \\
\hline DJ & 0.902 & 21 & 66 & 120 & 7.6 & 1.889 & 0.305 & 64 \\
\hline GF & 0.908 & 15 & 44 & 118 & 5.6 & 1.625 & 0.262 & 72 \\
\hline MT & 0.806 & 9 & 32 & 126 & 4.2 & 3.305 & 0.533 & 38 \\
\hline ED & 1.337 & 20 & 61 & 229 & 10.1 & 3.791 & 0.611 & 61 \\
\hline $\mathrm{CR}$ & 1.648 & 16 & 54 & 229 & 5.2 & 1.358 & 0.323 & 168 \\
\hline Mean & 1.004 & 16 & 49 & 153 & 6.61 & 2.049 & 0.345 & 92.3 \\
\hline SD & 0.356 & 4 & 11.9 & 52 & 1.9 & 1.050 & 0.169 & 52 \\
\hline \multicolumn{9}{|l|}{ Recovered } \\
\hline RW & 1.297 & 30 & 130 & 166 & 11.4 & 1.543 & 0.249 & 107 \\
\hline DA & 1.586 & 17 & 73 & 217 & 6.8 & 2.744 & 0.443 & 79 \\
\hline $\mathrm{HC}$ & 1.017 & 20 & 92 & 124 & N.A. & 1.074 & 0.173 & 116 \\
\hline DJ & 1.646 & 21 & 93 & 271 & 10.4 & 3.148 & 0.508 & 86 \\
\hline BJ & 1.416 & 15 & 60 & 203 & 5.7 & 1.274 & 0.206 & 159 \\
\hline OJ & 1.493 & 17 & 67 & 227 & 6.0 & 2.668 & 0.430 & 82 \\
\hline MT & 1.911 & 18 & 69 & 182 & 4.8 & 2.426 & 0.391 & 75 \\
\hline $\mathrm{CR}$ & 4.897 & 37 & 155 & 728 & 14.5 & 4.162 & 0.671 & 175 \\
\hline Mean & 1.907 & 22 & 92.4 & 265 & 8.5 & 2.380 & 0.384 & 110 \\
\hline SD & 1.236 & 8 & 33.7 & 192 & 3.6 & 1.043 & 0.168 & 38 \\
\hline
\end{tabular}


nutritional state. It follows from this that turnover is also not influenced by the size of the creatine pool, which increased by an average of $52 \%$ in the paired studies after recovery from malnutrition. Waterlow et al. (32) reported that in the rat, creatine turnover appeared to be little affected by age, sex, level of protein intake, and rate of weight gain or loss. There appears to be a remarkably narrow range of values for creatine turnover in the mouse, rat, dog, and man (32).

Muscle creatine concentration (micrograms $\mathrm{mg}^{-1}$ wet wt muscle) varied appreciably between individuals in both the malnourished and recovered groups (coefficient of variance, $13 \%$ and $14 \%$, respectively). This may well be a reflection of the variation in the rate of creatine synthesis in man (10). Creatinine output, which has been used to estimate muscle mass (14), depends, among other things, on the muscle creatine concentration and turnover, both of which showed significant variation between individuals in the malnourished and recovered groups. The dietary intake of creatine and creatinine are known to influence the urinary excretion of creatinine (12). It has been suggested that creatinine excretion merely reflects the dietary intake of creatine (4). In a recent report the addition of creatine to the diet led to an increase in the daily creatinine excretion (9) and the subsequent feeding of a creatine-free diet resulted in a decrease in creatine pool size and urinary creatinine excretion (10). These authors have concluded that creatinine output can change independently of lean body mass. The data presented in this and other studies $(9,10,25)$ support the view that there may be considerable error in predicting muscle mass from the daily excretion of urinary creatinine.

Of necessity the recovered studies were carried out some 2 months after the malnourished studies. In consequence any difference that is demonstrated between the groups tends to be the superimposition of two processes: the normal changes in growth and development that would have taken place over that period, plus the additional changes due to the repletion of tissues during recovery from malnutrition. We can try to differentiate the two processes either by looking at relative differences in the changes taking place within the study group itself, or, more ideally, we would like to be able to compare the changes we have observed with a suitable reference population. Data from the paired studies (Table 6) show that the increase in muscle mass $(130 \%)$ and muscle noncollagen protein $(116 \%)$ after recovery was greater than the increase in either body weight $(56 \%)$ or total body solids $(45 \%)$. These results confirm the suggestion that body weight deficit underestimates the extent of loss of muscle mass (30). One indicator of the abnormal body composition in PEM is the lower value for muscle mass as a percentage of body weight in the malnourished as compared to the recovered group.

Cheek et al. (7) calculated the muscle mass in malnourished and recovered children from the measured 24-hr excretion of creatinine in the urine, as described by Graystone (14). The ages of the children in their series were not significantly different from the ages of the children described here. When the two sets of data are compared on a group basis there is no significant difference in the mean muscle mass between the respective malnourished groups, nor is there any difference between the two groups after recovery. A comparison was made with the muscle mass of normal children of a similar age (6). The value of $22 \%$ for the recovered children is the same as that reported for normal male infants $0.2-2$ years of age. The muscle mass of the malnourished children was significantly lower than normal. If the muscle mass was related to height rather than to age for the same children, then the increase with recovery brings the muscle mass to $92 \%$ of the expected value for their height. This suggests that the recovered children had repleted their muscle mass in relation to their weight and height.

The average total muscle DNA was not significantly different in the malnourished and recovered groups. In the paired studies total muscle DNA increased considerably after recovery (mean

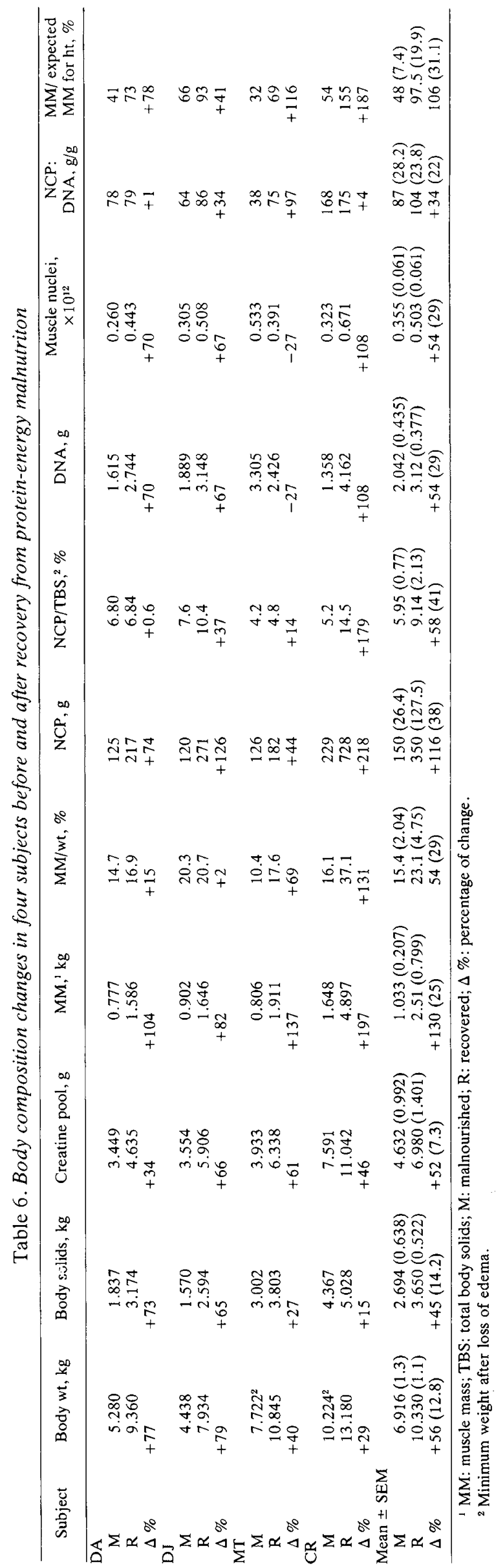


$+55 \%$ ), although in one study were was a decrease $(-27 \%)$. It is not possible to equate total muscle DNA with total myofibrillar nuclei. Cheek et al. (8) have pointed out that during normal growth $25 \%$ of nuclei in human muscle may be outside the myofiber. Histologic studies of muscle biopsies from malnourished and recovered children in this unit have revealed that approximately two-thirds of the total nuclei count was accounted for by muscle nuclei in both the malnourished and recovered groups. Of these nuclei, those classified as myogenic, including presumptive myoblasts, myoblasts, and myotubes, made up a significantly greater percentage in the recovered than in the malnourished children (16). One child showed a fall in DNA with recovery. His initial biopsy, obtained when he was malnourished, showed an excess of nonmyofibrillar nuclei, and was considered to be technically unsatisfactory and probably unrepresentative of the muscle mass.

It is not possible to measure fiber size in a biochemical analysis. However the concept of "cell size," as the ratio of noncollagen protein to DNA, has been found useful as a functional expression of the active protoplasmic mass per nucleus or physiologic muscle cell (8). Because of the uncertain contribution of nonmyofibrillar nuclei to the total muscle DNA, the absolute value for the ratio of NCP:DNA for the muscle cell is uncertain. However, total muscle NCP per total muscle DNA may be considered to be a minimum estimate of average "cell size" as any contribution from nonmuscle nuclei would tend to lower the ratio. The increase in the ratio of NCP:DNA during recovery $(34 \%)$ shows that cellular hypertrophy plays a role in the repletion of muscle mass. The finding that total DNA increases by $55 \%$ suggests that hyperplasia is also of importance, and that during recovery, muscle mass is repleted by a process of both hypertrophy and hyperplasia.

When changes are expressed on the basis of group means, it is possible that important individual variations be masked. It is difficult to make definite statements on the basis of a small series; however, the data do indicate a trend. If the initial deficits of weights and heights are ranked and compared with the ranked values for changes in muscle, NCP, and weight there is the suggestion that the least stunted children are more wasted and during repletion lay down relatively more muscle tissue. If this is so then the suggestion that during rehabilitation from malnutrition children make "balanced tissue" will have to be reexamined. We would suggest that this is not necessarily so. There is not a single metabolic stress of malnutrition, and the spectrum of marasmus to kwashiorkor is indicative of the differences. During rehabilitation the balance of tissues being repleted may vary depending upon the relative degree of stunting and wasting (17).

The changes in creatinine height index were similar to those reported previously (28). The creatinine excretion was highly correlated with body weight throughout recovery, irrespective of nutritional state $(r=0.795, n=126, P<0.001)$ provided that a correction was made in body weight for the presence of edema. This reflects the use of this index as a measurement of weight deficit in relation to height. The close relationship between daily creatinine excretion and body weight in normal infants has been ascribed to the muscle mass making up a fixed percentage of body weight $(25 \%)$ during the first year of life (5). Our finding that this relationship holds in a variety of nutritional states when body composition is not necessarily normal suggests that muscle mass itself may not be the sole determinant of creatinine excretion.

An unexpected finding was that TBW\% was the same in the malnourished and recovered groups. Similar results were obtained when paired data from four subjects were analyzed. All but one of the seven malnourished children were nonedematous, and none were dehydrated at the time of study. We have subsequently shown that TBW\% in marasmic children on admission did not differ significantly from values obtained after recovery (24).

\section{CONCLUSION}

This study has demonstrated that during recovery from malnutrition there is a significant increase in muscle mass. This increase is proportionately greater than the increase in body weight, and may differ according to the initial degree of stunting or wasting. The evidence suggests that both hypertrophy and hyperplasia may take place, but the extent to which each process contributes to the muscle repletion has not been clarified and further work is required to elucidate this point.

\section{REFERENCES AND NOTES}

1. Alleyne, G. A. O., Viteri, F., and Alvarado, J.: Indices of body composition in infantile malnutrition: Total body potassium and urinary creatinine. Amer. J. Clin. Nutr., 23: 875 (1970).

2. Ashworth, A.: Growth rates in children recovering from protein-calorie malnutrition. Brit. J. Nutr., 23: 835 (1969).

3. Bernt, E., Bergmeyer, H. U., and Mullering, H.: Methods of Enzymatic Analysis, p. 407 (Academic Press, New York, 1963)

4. Bleiler, R. E., and Schedl, H. P.: Creatinine excretion: Variability and relationships to diet and body size. J. Lab. Clin. Med., 59: 945 (1962).

5. Catherwood, R., and Stearns, G.: Creatine and creatinine excretion in infancy. J. Biol. Chem., 119: 201 (1937).

6. Cheek, D. B.: In: Human Gorwth (Lea \& Febiger, Philadelphia, 1968)

7. Cheek, D. B., Hill, D. E., Cordano, A., and Graham, G. G.: Malnutrition in infancy: Changes in muscle and adipose tissue before and after rehabilitation. Pediat. Res., 4: 135 (1970)

8. Cheek, D. B., Holt, A. B., Hill, D. E., and Talbert, J. L.: Skeletal muscle cell mass and growth: the concept of the deoxyribonucleic acid unit. Pediat. Res., 5: 312 (1971).

9. Crim, M. C., Calloway, D. H., and Margen, S.: Creatine metabolism in men: urinary creatine and creatinine excretion with creatine feeding. J. Nutr., 105: 428 (1975)

10. Crim, M. C., Calloway, D. H., and Margen, S.: Creatine metabolism in men creatine pool size and turnover in relation to creatine intake. J. Nutr., 106: 371 (1976).

11. Enesco, M., and Puddy, D.: Increase in the number of nuclei and weights in skeletal muscle of rats of various ages. Amer. J. Anat., 114: 235 (1964).

12. Folin, O.: Amer. J. Physiol, 13: 145 (1905).

13. Graham, G. G., Cordano, A., Blizzard, R. M., and Cheek, D. B.: Infantile malnutrition: Changes in body composition during rehabilitation. Pediat. Res., 3: 579 (1969).

14. Graystone, J. E.: In: D. B. Cheek: Human Growth, p. 182 (Lea \& Febiger, Philadelphia, 1968).

15. Halliday, D .: Chemical composition of the whole body and individual tissues of two Jamaican children whose death resulted primarily from malnutrition. Clin. Sci., 33: 365 (1967).

16. Hansen-Smith, F., Picou, D., and Golden, M. H: N.: Quantitative analysis of nuclear populations in muscle from malnourished and recovered children. Pediat. Res., 12: 167 (1978).

17. Jackson, A. A., Picou, D., and Reeds, P. J.: The energy cost of repleting tissue deficits during recovery from protein-energy malnutrition. Amer. J. Clin. Nutr., 30: 1514 (1977)

18. Kerpel-Fronius, E., and Frank, K.: Einige Besonderheiten der Körperzusammensetzung und Wasserverteilung bei der Säughingsatrophie. Ann. Paediat 173: 321 (1949). [Quoted in Ref. 27.]

19. Kerr, D., Ashworth, A., Picou, D., Poulter, N., Seakins, A., Spady, D., and Wheeler, E.: Accelerated recovery from infant malnutrition with high calorie feeding. In: Endocrine Aspects of Malnutrition (Kroc Foundation Symposia Number 1, California 1973).

20. Kissane, V. M., and Robins, E.: The fluormetric measurement of deoxyribonucleic acid in animal tissues with special reference to the central nervous system. J. Biol. Chem., 233: 184 (1958)

21. Lowry, O. H., Rosebrough, N. J., Farr, A. L., and Randall, R. J.: Protein measurement with the Folin phenol reagent. J. Biol. Chem., 193: 265 (1951).

22. Meador, C. K., Kreisberg, R. A., Friday, J. P., Bowdoin, B., Coan, P., Armstrong, J., and Hazelrig, J. B.: Muscle mass determination by isotopic dilution of creatine $-{ }^{14} \mathrm{C}$. Metabolism, 17: 1104 (1968)

23. Montgomery, R. D.: Muscle morphology in infantile protein malnutrition. J Clin. Pathol., 15: 511 (1962).

24. Patrick, J., Reeds, P. J., Jackson, A. A., Seakins, A., and Picou, D. I. M. Total body water in malnutrition: The possible role of energy intake. Brit. J. Nutr., In press.

25. Picou, D., Reeds, P. J., Jackson, A., and Poulter, N.: The measurement of muscle mass in children using $\left[{ }^{15} \mathrm{~N}\right]$ creatine. Pediat. Res., 10: 184 (1976)

26. Snedecor, G. W., and Cochran, W. G.: In: Statistical Methods, Ed. 6 (Iowa State University Press, Iowa, 1967).

27. Standard, K. L., Wills, V. G., and Waterlow, J. C.: Indirect indicators of muscle mass in malnourished children. Amer. J. Clin. Nutr., 7: 271 (1959).

28. Viteri, F., and Alvarado, J.: Creatinine height index. Pediatrics, 46: 696 (1970).

29. Waterlow, J. C.: The assessment of protein nutrition and metabolism in the whole animal, with special reference to man. In: Mammalian Protein Metabolism, Vol. 3, p. 325 (Academic Press, New York, 1969). 
30. Waterlow, J. C., Cravioto, J., and Stephen, J. M. L.: Protein malnutrition in man. Advan. Protein Chem., 15: 131 (1960).

31. Waterlow, J. C., and Mendes, C. B.: Composition of muscle in malnourished human infants. Nature, 180: 1361 (1957).

32. Waterlow, J. C., Neale, R. J., Rowe, L., and Palin, I.: Effects of diet and infection on creatine turnover in the rat. Amer. J. Clin. Nutr., 25: 371 (1972).

33. Wellcome Classification: Lancet, ii: 302 (1970).

34. ${ }^{15} \mathrm{~N}$ in excess of that due to the natural abundance in the compound is referred to as excess ${ }^{15} \mathrm{~N}$

35. We acknowledge the support provided by the Medical Research Council which enabled Dr. P. Reeds to carry out this research.

0031-3998/78/1205-0613\$02.00/0

Copyright (c) 1978 International Pediatric Research Foundation, Inc.
36. We wish to thank Mrs. Hazel MacDonald and Mrs. Yvonne Gayle for their skilled technical assistance, and Mr. G. Walling for his help in servicing the mass spectrometer.

37. This research was partly supported by the Wellcome Trust who donated the mass spectrometer and provided Dr. A. Jackson and Mr. N. Poulter with Research Fellowships.

38. Requests for reprints should be addressed to: D. Picou, M.B., Ph.D., Director, Tropical Metabolism Research Unit, University of the West Indies, Mona, Kingston 7, Jamaica (WI)

39. Received for publication October 13, 1976

40. Accepted for publication August 16, 1977.

Printed in U.S.A. 